Pak. j. sci. ind. res. Ser. A: phys. sci. 2021 64A(1) 46-51

\title{
Soil Characteristics and Fertility Indexation in Gujar Khan Area of Rawalpindi
}

\author{
Obaid ur Rehman**, Shahzada Munawar Mehdib, Raja Abad ${ }^{\mathrm{a}}$, Shahid Saleem ${ }^{\mathrm{a}}$, \\ Rizwan Khalid ${ }^{a}$, Sarosh Tariq Alvi ${ }^{\mathrm{a}}$ and Asia Munir ${ }^{\mathrm{a}}$ \\ ${ }^{a}$ Soil \& Water Testing Laboratory for Research, Rawalpindi, Pakistan \\ ${ }^{b}$ Director Soil Fertility Research Institute, Punjab, Lahore, Pakistan
}

(received April 2, 2018; revised November 21, 2019; accepted December 9, 2019)

\begin{abstract}
Soil characteristics of Gujar Khan area of Rawalpindi district were evaluated through physical and chemical analysis. About 3002 soil samples were received/collected from farmers' fields of Gujar Khan during the period between 2012 and 2017 and analysed for texture, electrical conductivity (ECe), $\mathrm{pH}$, organic matter (OM), available phosphorus (AP) and available potash (AK). The analysis results revealed that texture of the soils varied from sandy loam $(33.5 \%)$ to loam $(61.6 \%)$. The $98.6 \%$ soils had ECe values within the normal range $(<4 \mathrm{dS} / \mathrm{m})$ and almost $74 \%$ soil had from 7.5 to $8.5 \mathrm{pH}$ values with an average of 7.76. Thus there was no salinity/alkanity hazard in the area. Generally most of the soils were poor from the fertility point of view. About $96 \%$ soils were poor in both OM and AP contents, whereas, $3.0 \%$ soils have OM $(>0.86 \%)$ and 3.4\% satisfactory levels and AP ( $>7.0-14 \mathrm{mg} / \mathrm{Kg})$. However, $62 \%$ soils has satisfactory to adequate AK status. The frequency distribution analysis indicated that $45 \%$ soils of Gujar Khan and OM content in the range of $0.4-0.6 \%, 57 \%$ and soil have AP in the range of 4.0-6.0 mg/Kg, while $50 \%$ and AK in the range of $81-120 \mathrm{mg} / \mathrm{Kg}$. The soil fertility indexes in respect of OM and AP were low (1.0), whereas AK (1.7) indicating a medium fertility status of Gujar Khan soils.
\end{abstract}

Keywords: soil characteristics, Pothwar, NPK, Gujar Khan, fertility index

\section{Introduction}

In the North Eastern part of the Punjab province of Pakistan (latitude $32^{\circ} 10^{\prime}$ to $34^{\circ} 9^{\prime} \mathrm{N}$ and longitude $71^{\circ}$ $10^{\prime}$ to $\left.71^{\circ} 55^{\prime} \mathrm{E}\right)$, the Pothwar plateau comprises of the district of Attock, Jhelum, Chakwal and Rawalpindi. It covers an area of 1.82 million ha, and topography ranges from flat to gently undulating, locally broken by gullies and low hill ranges. In general, the Pothwar soils are alkaline, calcareous, low in organic matter and deficient in plant nutrients like $\mathrm{N}$ and $\mathrm{P}$ (Khan and Joergensen, 2006; Nizami et al., 2004). Although it constitutes an important area for rainfed agriculture in the country, however crop yields are low as compared to irrigated regions of Pakistan. Main cause of low production are, highly erratic rainfall, water erosion and widespread deficiency of plant nutrients. Due to the loss of fine soil particles along with essential plant nutrients through runoff and inadequate fertilization, the soils of Pothwar suffer with multiple nutrient deficiencies (Rashid et al., 1997). In general, the Pothwar soils are alkaline, calcareous, low in organic matter and deficient in plant nutrients like nitrogen and phosphorus.

*Author for correspondence;

E-mail: agrichemist.rwp@gmail.com
Soil analysis is useful instrument for assessing the amount of nutrients availability. It is a rapid and less expensive method for evaluation of fertility status of soil and for recommendation of optimum fertilizer rates for economic crop production. There is a network of soil and water testing laboratories established throughout the country under the provincial setup. These laboratories are designed to meet the routine needs of farmers i.e. water analysis, soil analysis for texture, salinity/sodicity, and fertility status (Ahmed and Rashid, 2003).

The Gujar Khan area fall in Rawalpindi district lies between latitude $33^{\circ} 10^{\prime}$ to $33^{\circ} 15^{\prime} \mathrm{N}$ and longitude $73^{\circ}$ $15^{\prime}$ to $73^{\circ}-20^{\prime}$ E. Soils of this area derived their parent material of underlying rocks like sandstone, limestone and shale, have medium (loam) to light (sandy loam) texture, poor fertility status in terms of organic matter and available phosphorus (Shaheen, 2016; Mahmood et al., 2010). However, majority of soils of Gujar Khan are generally well supplied with potassium (Khalid et al., 2002). Objective of this study is to evaluate soil fertility status of Gujar Khan area on the basis of soils samples collected from different areas during the years 2012-17. 


\section{Material and Methods}

During the year 2012-17 approximately 3002 soil samples were either collected or obtained from farmers at the soil and water Testing Laboratory, Rawalpindi, Pakistan. Samples were dried, sieved and analysed for physico-chemical characteristics i.e., texture, $\mathrm{EC}_{\mathrm{e}}, \mathrm{pH}$, soil organic matter, available $\mathrm{P}$ and available $\mathrm{K}$ by methods described by Page (1982). Soil texture was determined by measuring saturation percentage and Electrical Conductivity (ECe) by preparing soil and water (1:10) suspension (Malik et al., 1984a). The data was analysed using the MS Excel package for statistical analysis, shown in Table 1. Soil nutrient Index (SNI) was also calculated by following formula (Parker, 1951).

Nutrient Index $(\mathrm{NI})=\left(\left(\mathrm{N}_{\mathrm{i}} \times 1\right)+\left(\mathrm{N}_{\mathrm{m}} \times 2\right)+\right.$ $\left.\left(\mathrm{N}_{\mathrm{h}} \times 3\right)\right) / \mathrm{N}_{\mathrm{t}}$

where:

$\mathrm{N}_{\mathrm{t}}=$ Total number of samples analyzed in a given area; $\mathrm{N}_{\mathrm{i}}=$ Number of samples falling in low category of given nutrient; $\mathrm{N}_{\mathrm{m}}=$ Number of samples falling in medium category of given nutrient; $\mathrm{N}_{\mathrm{h}}=$ Number of samples falling in high category of given nutrient.

The following criteria has been used for the categorisation of soil samples Malik et al. (1984a)

\section{Results and Discussion}

Soil texture. Soil texture is basic with many other properties and used as an indicator of water and nutrient holding capacity of soil. It is also a major factor in defining the proper soil management practices to be followed. Generally the soils of Gujar Khan area are light to medium textured. The analysis data showed that $33.5 \%$ soils was light and $61.6 \%$ was medium textured (Table 2), whereas the proportion of heavy soil was just $4.9 \%$. Khalid et al. (2002) reported $65 \%$ of soils as medium textured loam in Gujar Khan area. The soils of Gujar khan area derived from loess and sandstone parent material, moderately to severely eroded, have medium to light texture (Nizami et al., 2004). These light textured soils with less water holding capacity needs to be enhance through addition of organic manures. The medium textured (loam) soils, however, these are suitable for cultivation of all common crops. Ho et al. (2019) found siliceous sandy nature Spodosols soils in Sabal area of Malaysia, poor in nutrient retention capacity due to sandstone parent material and low clay contents.
Soil salinity/sodicity. In Gujar Khan region, the electrical conductivity (ECe) of most of the soil (98.6\%) was within normal range $(<4.0 \mathrm{dS} / \mathrm{m})$ only $1.4 \%$ had salinity/ sodicity with values $>4.0 \mathrm{dS} / \mathrm{m}$. The soil $\mathrm{pH}$ ranged from 7.0 to 8.6 with in average value of 7.76 (Table 3 ). The data showed that $26 \%$ soils has $\mathrm{pH}>7.5$, while, $74 \%$ has $7.5-8.5$ (Table 3). The soils have $\mathrm{pH}<8.5$ are considered as normal, while those having $\mathrm{pH}$ value $>$ 8.5 as sodic. However, these were very rare $(0.1 \%)$ in the study area (Table 2-3). Similar results were also reported by Shaheen (2016) and Fateh et al., (2006) for Gujar Khan area.

Table 1. Soil statistical analysis

\begin{tabular}{|c|c|c|c|}
\hline \multirow[t]{2}{*}{ (a) } & \multicolumn{3}{|l|}{$\begin{array}{l}\text { Soil texture } \\
\text { SP }(\%)\end{array}$} \\
\hline & $\begin{array}{l}19 \\
20-30 \\
31-45 \\
46-60 \\
>60\end{array}$ & $\begin{array}{l}\text { Sandy } \\
\text { Sandy loam } \\
\text { Loam } \\
\text { Clay loam } \\
\text { Clay }\end{array}$ & \\
\hline \multirow[t]{2}{*}{ (b) } & \multicolumn{3}{|c|}{ Soil salinity/sodicity } \\
\hline & $\begin{array}{l}<4.0 \\
>4.0 \\
>4.0 \\
<4.0\end{array}$ & $\begin{array}{l}7.0-8.1 \\
7.0-8.5 \\
>8.5 \\
>8.5\end{array}$ & $\begin{array}{l}\text { Normal } \\
\text { Saline soil } \\
\text { Saline-Sodic soil } \\
\text { Sodic soil }\end{array}$ \\
\hline \multirow[t]{7}{*}{ (c) } & \multicolumn{2}{|c|}{$\begin{array}{l}\text { Essential soil nutrients } \\
\text { Organic matter }(\%)\end{array}$} & Remarks \\
\hline & $\begin{array}{l}<0.86 \\
0.86-1.29 \\
>1.29\end{array}$ & & $\begin{array}{l}\text { Poor } \\
\text { Satisfactory } \\
\text { Adequate }\end{array}$ \\
\hline & Phosphorus & $\mathrm{Kg})$ & Rating \\
\hline & $\begin{array}{l}<7.0 \\
7.1-14.0 \\
14.0-21.0 \\
>21.0\end{array}$ & & $\begin{array}{l}\text { Poor } \\
\text { Medium } \\
\text { High } \\
\text { Very high }\end{array}$ \\
\hline & Potassium (n & & Rating \\
\hline & $\begin{array}{l}<80 \\
80-180\end{array}$ & & $\begin{array}{l}\text { Poor } \\
\text { Satisfactory }\end{array}$ \\
\hline & $>180$ & & Rich \\
\hline
\end{tabular}

$\mathrm{a}=$ soil texure; $\mathrm{b}=$ salinity/sodicity; $\mathrm{c}=$ essential soil nutrients.

Table 2. Soil characteristics of Gujar Khan

\begin{tabular}{llll}
\hline \hline Parameter & Range & Mean & SD \\
\hline Soil pH & $7.0-8.6$ & 7.76 & 0.26 \\
EC & $0.15-6.02$ & 0.79 & 0.07 \\
Organic matter & $0.23-1.29$ & 0.53 & 0.25 \\
Available phosphorus & $2.3-17.2$ & 3.89 & 0.58 \\
Available potash & $40-320$ & 103 & 12.01 \\
\hline \hline
\end{tabular}


Soil fertility status. The fertility status of the Gujar Khan soils was determined through estimation of organic matter for nitrogen, available phosphorus and potash. The results based up on analytical data are given as under.

Organic matter. Soil nitrogen requirement usually recommended on the basis of nitrogen released by the organic matter $(\mathrm{OM})$ contents by soil testing laboratories (Cooke, 1982). There is a significant positive correlation between $\mathrm{N}$ and $\mathrm{OM}$ indicating that $\mathrm{N}$ nutrition of crops largely depends on the maintenance of organic matter levels in soil (Tsozue et al., 2016). The present data revealed that the OM ranges from $0.23-1.29 \%$ in the area with mean value of 0.53 (Tables 2). Majority (97\%) of soils of Gujar Khan area had poor $(<0.86 \%)$ while, rest had satisfactory to adequate OM contents (Table 3). The frequency distribution data indicated that $45 \%$ fall in the range of 0.41 to $0.60 \%$ followed by $33 \%$ in $0.21-0.40 \%$ whereas, only $1.2 \%$ had OM contents more than 1\% (Table 4). However, Shaheen (2016) reported $\mathrm{OM}$ in the range of 0.89 to $1.25 \%$ in eroded soils of Gujar Khan area. Khalid et al. (2012) reported OM content in the range of $0.4-0.6 \%$, in soils of Chakwal.

Organic matter makes its greatest contribution to soil productivity not only by providing nutrients but also improving its water holding capacity and physical properties (Sarwari et al., 2008). The soils of Pakistan are quite low in organic matter. Atreya et al. (2005) associated much of the soil OM loss from farm fields with the eroded sediments. Thus, higher the soil loss higher will be the soil OM losses. Erosion reduces organic matter and ultimately soil fertility. Soil fertility declination due to soil erosion and nutrients losses through runoff is a serious problem of hilly areas

Table 3. Analysis of Gujar Khan soil samples during the years 2012-17

\begin{tabular}{|c|c|c|c|c|c|c|c|c|}
\hline \multirow{2}{*}{\multicolumn{2}{|c|}{ Particulars }} & \multicolumn{7}{|c|}{ Year } \\
\hline & & \multirow[t]{2}{*}{$2012-13$} & \multirow[t]{2}{*}{ 2013-14 } & \multirow[t]{2}{*}{$2014-15$} & \multirow[t]{2}{*}{$2015-16$} & \multirow[t]{2}{*}{ 2016-17 } & \multirow[t]{2}{*}{ Total } & \multirow[t]{2}{*}{$(\%)$} \\
\hline a. & Soil texture & & & & & & & \\
\hline 1. & Light & 2 & 733 & 288 & 281 & 203 & 1507 & 33.5 \\
\hline 2. & Medium & 40 & 687 & 622 & 941 & 486 & 2776 & 61.6 \\
\hline 3. & Heavy & 2 & 39 & 34 & 26 & 120 & 221 & 4.9 \\
\hline \multicolumn{9}{|c|}{ b. Salinity/sodicity } \\
\hline 1. & Normal $(\mathrm{ECe}<4.0)$ & 43 & 1439 & 941 & 1220 & 799 & 4442 & 98.6 \\
\hline & Saline $(\mathrm{ECe}>4.0)$ & 1 & 20 & 3 & 28 & 10 & 62 & 1.4 \\
\hline \multicolumn{9}{|c|}{ c. Soil pH } \\
\hline 1. & $>7.5$ & 30 & 733 & 142 & 182 & 80 & 1167 & 25.9 \\
\hline 2. & $7.5-8.5$ & 14 & 729 & 802 & 1066 & 720 & 3331 & 73.9 \\
\hline 3. & $>8.5$ & & 6 & & & & 6 & 0.1 \\
\hline \multicolumn{9}{|c|}{ d. Oraganic matter } \\
\hline 1. & Poor $(<0.86 \%)$ & 41 & 1371 & 935 & 1213 & 797 & 4357 & 96.7 \\
\hline & Satisfactory $(0.86-1.29 \%)$ & 2 & 80 & 9 & 35 & 8 & 134 & 3.0 \\
\hline 3. & Adequate $(>1.29 \%)$ & 1 & 7 & 0 & & 5 & 13 & 0.3 \\
\hline \multicolumn{9}{|c|}{ e. Available phosphorous } \\
\hline 1. & Poor $(<7.0 \mathrm{mg} / \mathrm{Kg})$ & 37 & 1404 & 921 & 1196 & 767 & 4325 & 96.0 \\
\hline & Satisfactory $(7.0-14.0 \mathrm{mg} / \mathrm{Kg})$ & 6 & 51 & 18 & 46 & 30 & 151 & 3.4 \\
\hline 3. & Adequate $(>14 \mathrm{mg} / \mathrm{Kg})$ & 1 & 3 & 5 & 6 & 13 & 28 & 0.6 \\
\hline \multicolumn{9}{|c|}{ f. Available potash } \\
\hline & Poor $(<80 \mathrm{mg} / \mathrm{Kg})$ & 3 & 566 & 235 & 333 & 288 & 1425 & 31.6 \\
\hline & Satisfactory $(80-180 \mathrm{mg} / \mathrm{Kg})$ & 39 & 805 & 633 & 836 & 481 & 2794 & 62.0 \\
\hline & Adequate $(>180 \mathrm{mg} / \mathrm{Kg})$ & 2 & 87 & 76 & 79 & 41 & 285 & 6.3 \\
\hline
\end{tabular}


(Tripathi et al., 2000). The presence of vast eroded lands might be one of the main reasons of low organic matter contents in soils.

Available phosphorus. The data revealed that $96 \%$ soils of Gujar Khan were poor in available phosphorus (AP). About 3.4\% soils was satisfactory and only $0.6 \%$ was adequated ( $>14 \mathrm{mg} / \mathrm{Kg}$ ) AP contents (Table 3 ). The frequency distribution analysis indicated that majority of soils (57\%) in Gujar Khan area has AP in the range of 4.0-6.0 mg/Kg (Table 5), followed by $34 \%$ in 2.1 $4.0 \mathrm{mg} / \mathrm{Kg}$, whereas only $0.6 \%$ samples has $>14 \mathrm{mg} / \mathrm{Kg}$ AP contents. Shaheen (2016) reported phosphorus deficiency $(<7 \mathrm{mg} / \mathrm{Kg})$ in $95 \%$ soils of Gujar Khan. Similar results were reported by Khalid et al. (2012) for Chakwal soil of Pothwar areas. Malik et al. (1984b) and Rashid (1994) reported a wide spread phosphorus deficiency in Punjab and reported $75-95 \%$ soils are lacking this major nutrient. Kumar et al. (2017) described medium to low available P contents in Rajistan, India soils and low mobility of this nutrient in soil.

In soils with $\mathrm{pH} 7-8$, the soluble $\mathrm{H}_{2} \mathrm{PO}_{4}$ quickly reacts with calcium to form products of having less solubility.
The $\mathrm{pH}$ also affects the applied $\mathrm{P}$ fertilizer by changing it into extremely insoluble calcium phosphate form. This problem is common in calcareous soils (Ali et al., 2000). The poor AP status of Gujar Khan soils might be attributed to this phenomenon.

Available potash. The satisfactory level of available potassium (AK) contents was observed in the study area ranging from $40-320 \mathrm{mg} / \mathrm{Kg}$ with mean value of $103 \mathrm{mg} / \mathrm{Kg}$ (Tables 2). As many as $62 \%$ soils contained satisfactory, $6.3 \%$ which has adequate and $31.6 \%$ of poor $(<80 \mathrm{mg} / \mathrm{Kg}) \mathrm{AK}$ contents. The frequency distribution data (Table 6 ) indicated that $50 \%$ soil was AK ranged from $81-120$ followed by $30 \%$ in $40-80 \mathrm{mg} / \mathrm{Kg}$ ranged. Soils of Pakistan are generally considered rich in mica minerals, the rich source of natural potassium (Khattak and Hussain, 2007; Bajwa and Rehman, 1996). Similarly the high to medium range of available K in Rajistan soils of India was attributed by Kumar et al. (2017) to the presence of potash bearing minerals (Muscovites, biotits and feldspar) which on weathering slowly release potash. Available potash was invariably reported as adequate in Punjab soils except eroded or light texture soils (Khalid et al., 2002; Bajwa, 1990).

Table 4. Frequency distribution of Gujar Khan area soil samples for organic matter

\begin{tabular}{llllllll}
\hline $\begin{array}{l}\text { Organic matter } \\
\text { range (\%) }\end{array}$ & $2012-13$ & $2013-14$ & $2014-15$ & $2015-16$ & $2016-17$ & Total & (\%) \\
\hline $0.0-0.20$ & 0 & 195 & 89 & 13 & 76 & 373 & 8.3 \\
$0.21-0.40$ & 32 & 456 & 214 & 369 & 432 & 1503 & 33.4 \\
$0.41-0.60$ & 8 & 670 & 625 & 530 & 213 & 2046 & 45.4 \\
$0.61-0.80$ & 0 & 50 & 7 & 301 & 76 & 434 & 9.6 \\
$0.81-1.00$ & 3 & 59 & 6 & 18 & 8 & 94 & 2.1 \\
$1.01-1.20$ & 0 & 21 & 3 & 17 & 2 & 43 & 1.0 \\
$1.21-1.40$ & 1 & 7 & 0 & 0 & 3 & 0 & 0.2 \\
$>1.40$ & 0 & 0 & 0 & 0. & 0 & 0.0 \\
\hline \hline
\end{tabular}

Table 5. Frequency distribution of Gujar Khan area soil samples for Av. phosphorus

\begin{tabular}{llllllll}
\hline $\begin{array}{l}\text { Available P range } \\
(\mathrm{mg} / \mathrm{Kg})\end{array}$ & $2012-13$ & $2013-14$ & $2014-15$ & $2015-16$ & $2016-17$ & Total & $(\%)$ \\
\hline $0-2.0$ & 0 & 0 & 0 & 9 & 11 & 20 & 0.4 \\
$2.1-4.0$ & 30 & 1021 & 132 & 192 & 165 & 1540 & 34.2 \\
$4.0-6.0$ & 7 & 386 & 663 & 965 & 553 & 2574 & 57.1 \\
$6.1-8.0$ & 0 & 32 & 127 & 30 & 38 & 227 & 5.0 \\
$8.1-10.0$ & 2 & 12 & 2 & 14 & 5 & 35 & 0.8 \\
$10.1-12.0$ & 4 & 4 & 12 & 32 & 23 & 75 & 1.7 \\
$12.1-14.0$ & 0 & 0 & 2 & 0 & 3 & 5 & 0.1 \\
$>14.0$ & 1 & 3 & 5 & 6 & 12 & 27 & 0.6 \\
\hline \hline
\end{tabular}


Table 6. Frequency distribution of Gujar Khan area soil samples for Av. potash

\begin{tabular}{llllllll}
\hline $\begin{array}{l}\text { Available K range } \\
(\mathrm{mg} / \mathrm{Kg})\end{array}$ & $2012-13$ & $2013-14$ & $2014-15$ & $2015-16$ & $2016-17$ & Total & $(\%)$ \\
\hline $0-40$ & 0 & 34 & 0 & 21 & 13 & 68 & 1.5 \\
$41-80$ & 3 & 532 & 235 & 312 & 265 & 1347 & 29.9 \\
$81-120$ & 29 & 623 & 526 & 705 & 389 & 2272 & 50.4 \\
$121-160$ & 10 & 182 & 106 & 131 & 102 & 531 & 11.8 \\
$161-220$ & 2 & 65 & 59 & 63 & 34 & 223 & 5.0 \\
$221-260$ & 0 & 22 & 14 & 11 & 7 & 54 & 1.2 \\
$260-300$ & 0 & 0 & 3 & 5 & & 8 & 0.2 \\
$>300$ & 0 & 0 & 0 & 0 & 0 & 0 & 0.0 \\
\hline \hline
\end{tabular}

Table 7. Soil fertility index of soils in Gujar Khan area

\begin{tabular}{|c|c|c|c|c|}
\hline \multirow[t]{2}{*}{ Available nutrients } & Poor & Satisfactory & Adequate & \multirow{2}{*}{$\begin{array}{l}\text { Soil nutrient } \\
\text { index (SNI) }\end{array}$} \\
\hline & \multicolumn{3}{|c|}{$(\%)$} & \\
\hline $\begin{array}{l}\text { Organic matter/ } \\
\text { nitrogen }\end{array}$ & 96.7 & 3.0 & 0.3 & 1.04 \\
\hline $\begin{array}{l}\text { Available } \\
\text { phosphorus }\end{array}$ & 96.0 & 3.4 & 0.6 & 1.04 \\
\hline $\begin{array}{l}\text { Available } \\
\text { potassium }\end{array}$ & 31.6 & 62.0 & 6.3 & 1.74 \\
\hline
\end{tabular}

However, Rashid (1994) reported 30\% of surface soils in groundnut growing areas of Gujar Khan contained low AK-22-158 mg/Kg.

Soil fertility index (SFI). Soil fertility index at nutrient index value of $>2.5$ is taken as higher, while values between 1.5-2.5 indicates medium and $<1.5$ as low fertility status of the given area (Motsara, 2002). The fertility index values of Gujar Khan soils (Table 7) in respect of OM \& AP are low (1.04), whereas of AK (1.74) indicating a medium fertility status. Similar results are reported by Kausar et al., (2016) for Sargodah soils and Khalid et al. (2012) for Chakwal area of Pothwar. While, medium nutrient index values for organic carbon (2.3), available phosphorus (2.2) and high for potassium (3.0) are observed by Singh et al. (2018) in the soils of Varanasi district, UP, India.

Conflict of Interest. The authors declare no conflict of interest.

\section{Refrences}

Ahmed, N., Rashid, M. 2003. Fertilizer use in Pakistan. NFDC. Planning and development division, Islamabad, $141 \mathrm{pp}$.
Ali, M., Sarir, M.S., Shirazi, M.U., Alam, S.M., Ansari, R. 2000. Phosphorus mineralization in some soil series of Peshawar valley. Journal of Soil Science. 18: $13-18$.

Atreya, K., Sharma, S., Bajracharya, R.M. 2005. Minimization of soil and nutrient losses in maizebased cropping systems in the mid-hills of central Nepal. Kathmandu University. Journal of Science, Engineering and Technology, 1: 1-10.

Bajwa, M.1. 1990. Soil fertility management for sustainable agriculture. In: Proceeding $3^{\text {rd }}$ National Congress of Soil Science, March 20-22, pp. 7-23, Lahore, Pakistan.

Bajwa, M.I., Rehman, F. 1996. Soil and fertilizer potassium. In: Soil Science, Rashid, A. and Memon, K.S. (Managing Authors), pp. 317-338, National Book Foundation Islamabad, Pakistan.

Cooke, G.W. 1982. An introduction to soil analysis. World Crops, 1: 8-9.

Fateh, S., Arshad, M., Neem, M.A., Latif, I. 2006. Physioco-chemical characteristics of soil of Pothwar and determination of organic matter. Pakistan Journal of Biological Sciences, 9: 473-476.

Soo Ying Ho, Wasli, M.E.B., Perumal, M. 2019. Evaluation of physic-ochemical properties of sandy-textured soils under small holder agricultural land use practices in Sarawak, east Malaysia. Applied and Environmental Soil Science, ID768545, (14 pages).

Khalid, R., Kashif, S.R., Naz, S.Y. 2002. Potassium status of Gujar Khan soils. Pakistan Journal of Soil Science, 21: 41-44.

Khan, K.S., Joergensen, R.G. 2006. Microbial C, N and P relationships in moisture stressed soils of Potohar, Pakistan. Journal of Plant Nutrition and Soil Science, 169: 494-500. 
Khalid, R., Mahmood, T., Bibi, R., Siddique, M.T. 2012. Distribution and indexation of plant available nutrients of rainfed calcareous soils of Pakistan. Soil and Environment, 31: 146-151.

Kausar, R., Azam, M., Nawaz, S., Ahmad, I., Iqbal, N. 2016. Indexing soil fertility status and suitability of groundwater in Sargodah district. Journal of Environment and Agriculture, 1: 12-21.

Khattak, R.A., Hussain, Z. 2007. Evaluation of soil fertility status and nutrition of orchards. Soil and Environment, 26: 22-32.

Kumar, D., Yadav, S.R., Kaur, R., Choudhary, A., Meena, B.J.S. 2017. Soil fertility status and nutrient recommendations based on soil analysis of Jaisalmer district of western Rajasthan. Asian Journal of Soil Science, 12: 103-107

Mahmood, S., Qazi, M.A., Ali, I. 2010. Annual Report 2008-09. Soil and Water Advisory Service in Punjab. Soil Fertility Research Institute, Department of Agriculture, Lahore, Pakistan.

Malik, D.M., Khan, M.A., Choudhry, T.A. 1984a. Analysis Manual for Soil, Water and Plants. Directorate of Soil Fertility and Soil Testing, Lahore, Pakistan.

Malik, D.M., Ahmed, B., Ahmed, M. 1984b. Survey of Soil Fertility Status and Quality of Ground Waters. Punjab Digest 1981-84 Lahore, Department of Agriculture, Punjab.

Motsara, M.R. 2002. Available nitrogen, phosphorus and potassium status of Indian soils as deicited by soil fertility maps. Fertilizer News, 47: 15-21.

Nizami, M.I., Shafiq, M., Rashid, A., Aslam, A. 2004. The Soils and Their Agricultural Development Potential in Pothwar. WRRI \& NARC, Islamabad, Pakistan. pp. 5-7.

Page, A.L. 1982. Method of Soil Analysis, Part 2,
Chemical and Microbiological Properties, $2^{\text {nd }}$ edition, American Society of Agronomy, Inc and Soil Science Society of America, Inc., Publisher, Madison, Wisconsin, USA.

Parkar, 1951. Agronomy Journal, 48: 105-112.

Rashid, A. 1994. Nutrient Indexing Surveys and Micronutrient Requirement of Crops. NARC, Islamabad, Pakistan.

Rashid, A., Rafique, E., Bughio, N. 1997. Micronutrient deficiencies in rainfed calcareous soils of Pakistan. I. Iron chloresis in peanut. Communication in Soil Science and Plant Analysis, 28: 135-148.

Sarwari, G., Hussain, N., Schmeisky, H., Suhammad, S., Ibrahim, M., Ahmad, S. 2008. Efficiency of various organic residues for enhancing rice-wheat production under normal soil conditions. Pakistan Journal of Botany, 40: 2107-2113.

Shaheen, A. 2016. Characterization of eroded lands of Pothwar plateau, Punjab, Pakistan. Sarhad Journal of Agriculture, 32: 192-201.

Singh, S.P., Singh, S., Kumar, A., Kumar, R. 2018. Soil fertility evaluation for macronutrients using parkers nutrient index approach in some soils of varanasi district of eastern Utter Pradesh, India. International Journal of Pure and Applied Bioscience, 6: 542-548.

Tsozue, B.P., Shrestha, S.P., Tamfuh, P.A. 2016. Relationship between soil characteristics and fertility implications in two typical dystrandept soils of the Cameroon western highland. International Journal of Soil Science, 11: 36-48.

Tripathi, B.P., Shrestha, S.P., Acharya, G.P. 2000. Summary and Updating with 1999 Season Soil and Nutrient Losses from Bari Land Terraces in the Western Hills of Nepal. Lumle technical paper No. 2000/2003. Lumle Agricultural Center, Kaski, Nepal. 